\section{AJHSE Vol: 1 (1): 11-21, 2020}

Article Ref. No.: AJHSE-0101-07

Accepted Date: Feb. 11, 2020

(C) 2020. CC License 4.0

www.ajhse.org

African Journal of Health, Safety and Environment

An official publication of the

Applied Environmental Bioscience and Public Health Research Group

University of Benin, Benin City, Nigeria

Open Access | Bi-annual | Peer-reviewed | International

ISSN (Online): 2695-1819 | ISSN (Print): 2695-2386

\title{
INDISCRIMINATE REFUSE DUMPING AND FLOODING IN AMASSOMA COMMUNITY, NIGERIA
}

\section{${ }^{* 1}$ Oleabhiele, E. J. and ${ }^{2}$ Dotimi, D. E.}

${ }^{*}$ Department of Sociology and Anthropology, Benson Idahosa University (BIU), Benin City, Nigeria.

*Phone: +2347051905660*Email: eoleabhiele@biu.edu.ng

${ }^{2}$ Yenogua, Balyesa State, Nigeria

*Email: divinedotimi@gmail.com

\begin{abstract}

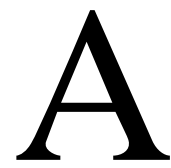
ppropriate waste disposal is crucial for a healthy environment and avoidance of health hazards. Environmental problems arising from indiscriminate dumping of refuse needs urgent attention, control and management in Nigeria. This study sought to examine the relationship between indiscriminate refuse
\end{abstract} dumping and flooding in Amassoma community of Bayelsa State, Nigeria. The study was anchored on structuralfunctionalist theory. The study engaged the survey research design and its population comprised residents of Amassoma community and staff of Bayelsa State Environmental Sanitation Authority. A triangulation of both quantitative and qualitative method of data collection was used. Quantitatively, a sample size of 378 were administered closed ended structured questionnaires which elicited information based on the study's objectives, while qualitatively, 5 respondents participated in the study's in-depth interview which allowed for participants to disclose their feelings and attitude more readily about the subject matter. The non-probability sampling technique involving the use of accidental sampling was employed in selecting the study respondents. Quantitative data were analyzed using the nonparametric method of Chi-square, while qualitative data was content analyzed using verbatim quotations. The study findings revealed that there was a significant relationship between the waste disposal habit of the people and flooding and also, between poor waste management and flooding in the study area. It also revealed a significant relationship between drains blocked by refuse dumping and flooding in Amassoma community. The study therefore recommends a communal orientation on the need for proper waste disposal for residents of Amassoma community to ensure positive attitude towards waste management and, effective control of indiscriminate refuse dumping in drains, so as to reduce the incidence of flooding in the community.

Keywords: Amassoma community, Bayelsa State, drains, flooding, indiscriminate refuse dumping, Nigeria

LICENSE: This article by African Journal of Health, Safety and Environment (AJHSE)is licensed and published under the Creative Commons Attribution License 4.0 International License, which permits unrestricted use, distribution, and reproduction in any medium, provided this article is duly cited. 


\section{INTRODUCTION}

In both developed and developing countries, a lot of human activities on the environment are currently responsible for most of the environmental problems experienced in our societies. However, in developing societies, one of such human activity on the environment involves the problem of indiscriminate refuse dumping. Studies carried out in Nigeria and Ghana revealed that about $80 \%$ of solid wastes are indiscriminately discarded (Ogwueleka, 2009; Aziale and AsafoAdjei, 2013).

It has been observed in Nigeria, that the few environmental regulatory agencies like the Federal and State Waste Management Boards that exists, have not been effective in attaining a safe and healthy environment for residents (Ogwueleka, 2009; Karanja, 2015; Omolawal and Shittu, 2016). There also appears to be no strict regulations guiding the populace habits and the concomitant implications of their activities in the environment. For instance, in most urban areas, it is common to see heaps of refuse disposed on the road side, and in market places. When people inappropriately litter waste and dirt in gutters, roads, open spaces, the drains become blocked and limit free flow of water. Moreover, when it rains, it causes flooding resulting to damaging effects on properties with severe consequences on the livelihood of individuals and health hazards (Akinwale, 2010; Akindutire and Alebiosu, 2014; Olayiwola et al., 2017).

The issue of flooding is a reoccurring phenomenon in most parts of the country situated around the coastal regions. In recent times, evidence suggests that floods have become increasingly common and intense in coastal areas like Lagos and Bayelsa State given that they are prone to storm surges (Akinwale, 2010; Ifeoluwa, 2019). This present study believes that this problem is heightened by indiscriminate refuse dumping in the area. Therefore, the paper sought to examine the relationship between indiscriminate refuse dumping and flooding in the study location.

\section{AIM AND OBJECTIVES}

The main aim of the study was to examine the relationship between indiscriminate refuse dumping and flooding in Amassoma Community of Bayelsa State, Nigeria. Its specific objectives were to examine the relationship between:

1. the waste disposal habit of the people and flooding in the study area.

2. poor waste management and flooding in the study area.

3. drains blocked by dumped refuse and flooding in the study area.

\section{RESEARCH JUSTIFICATION}

The environmental problems arising from indiscriminate refuse dumping no doubt needs urgent attention and control.

\section{RESEARCH HYPOTHESES}

The following null hypotheses were formulated:

$\mathrm{Ho}_{1}$ : there is no relationship between waste disposal habit of the people and flooding in the study area.

$\boldsymbol{H o}_{2}$ : there is no relationship between poor waste management and flooding in the study area.

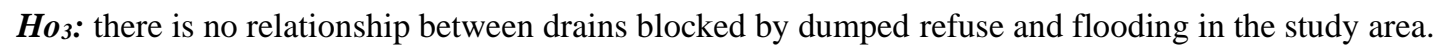




\section{LITERATURE REVIEW}

\section{CONCEPT OF INDISCRIMINATE REFUSE DUMPING}

Indiscriminate refuse dumping is the practice of dumping refuse without public health and environmental consideration. It involves the dumping of solid and liquid waste without taking necessary measures to dispose them appropriately (Aliu, 2017; Olayiwola et al., 2017). Indiscriminate dumping of refuse is a very common and unhealthy practice among people leading to various environmental problems and public health hazards in developing countries (Ogwueleke, 2009; Onifade and Nwabotu, 2014; Omolawal and Shittu, 2016).

Indiscriminate refuse dumping has become common place attitude of people such as; residents, passerby, road users and market women. For example, Ogwueleke (2009) in his study of solid waste management in PortHarcourt, Nigeria found out that $68 \%$ of the solid waste generated by communities was indiscriminately dumped while only $20.8 \%$ were disposed of through appropriate landfill sites and $10.7 \%$ of such waste was burnt.

According to Abolade et al. (2013), there are many causes of indiscriminate refuse dump which are, waste disposal habit of the people, population effect, poor waste management, attitude to work, avoidance of disposal fees at waste management sites, poverty and poor drainage system.

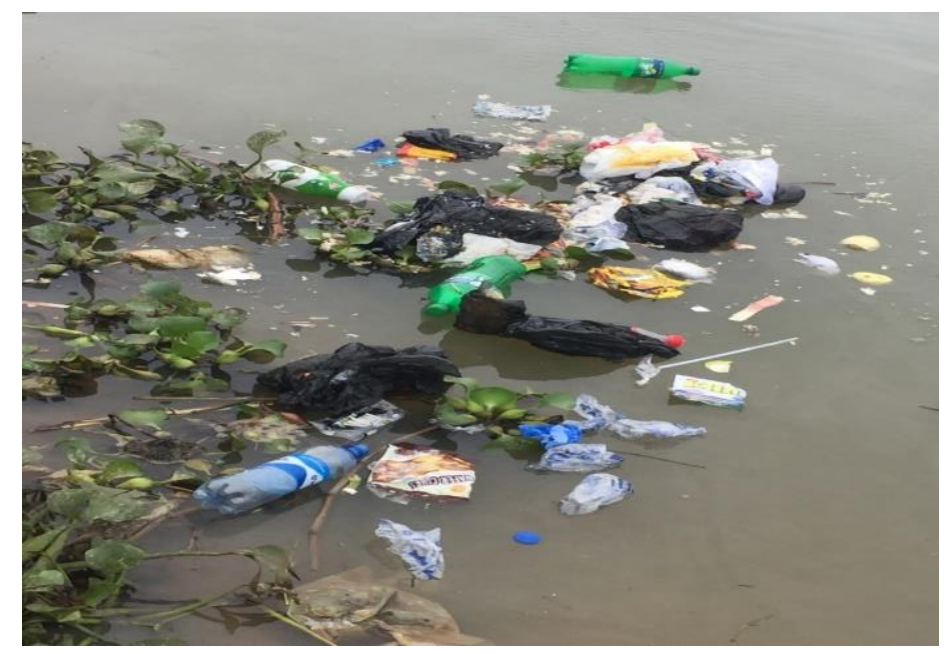

Figure 1: Indiscriminate refuse dumped in the river at Amassoma community

Source: (Field survey, 2019) 


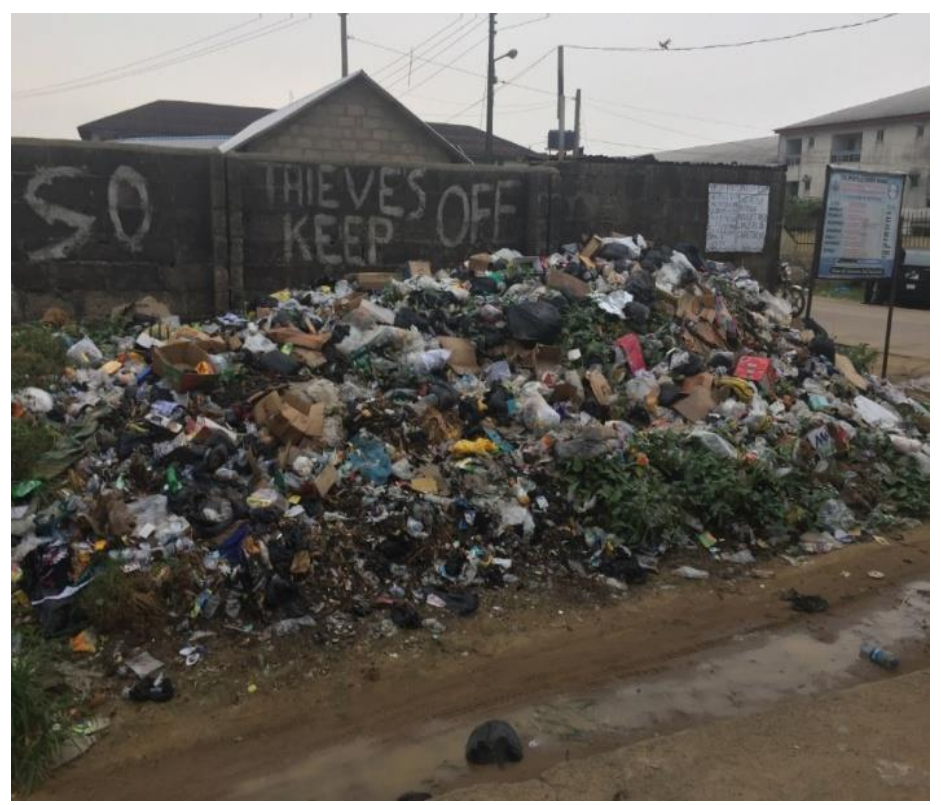

Figure 2: Indiscriminate refuse dumped in front of a compound at Amassoma Community.

Source: (Field survey, 2019)

\section{INDISCRIMINATE REFUSE DUMPING AND FLOODING}

The goal of a clean and healthy environment for residents can be hindered by the act of indiscriminate refuse dumping. This was observed by Taiwo and Ajayi (2013), who noted that in residential areas where refuse is indiscriminately dumped, it was easy to find huge piles of waste dumped by the roadsides. This situation could create potential health risk and hazards for residents and also undermine the goal for a healthy and safe environment.

When waste gets into the water or drains, it changes the chemical composition of the water negatively. This is called water pollution and this can cause harm to the animals that drink from that water. The blockage in the drains is another consequence of indiscriminate refuse dumping because when it rains heavily, it can disturb the free flow of erosion thereby resulting in flooding with adverse implications for life and properties.

Residents regularly dump their waste in gutters and this can clog the gutters and prevent the flow of water, causing the gutters to overflow. It is common to observe flooded streets with litters floating all over after rainfall. This can create very unsanitary conditions for the residents and contribute to the degradation of the environment. Indeed, there is a great need for proper waste disposal attitudes on the part of residents, effective waste management and better drainage system in order to avoid the potential threat of flooding.

\section{MATERIALS AND METHODS}

The target population comprised both male and female residents in the study area and staff of Bayelsa State Environmental Sanitation Authority in Yenagoa. Amassoma community has a population of 321,808 under Southern Ijaw local government area (NBS, 2017). The sample size of 378 respondents was derived from the study's population using the Krejcie and Morgan (1970) Table for sample size determination. 


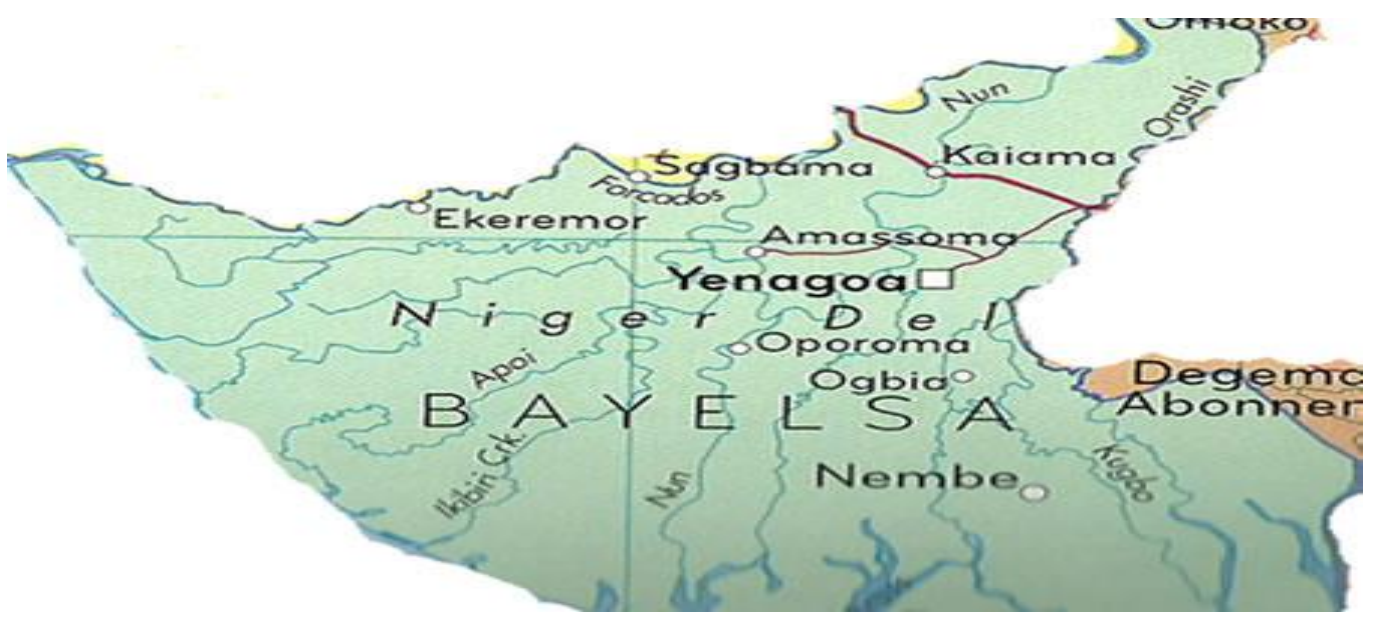

Figure 2: Study location

Source: (Google Maps, 2020)

The study employed a multistage sampling technique (Cochran, 1939) for collection of data. Firstly, the researcher used purposive sampling to select the study area given the severity of the subject matter in the area. The second stage involved the use of quota sampling technique to divide the study area into five quarters or areas; Tantuama, Ending-pele, Waduama, Foroama and Amafini. The third stage involved the use of accidental sampling to select the study's respondents from the five areas.

The research instruments involved the use of questionnaire and in-depth interview. The questionnaire contained thirty-one (31) items and was divided into four sections A-D. Section A, captured respondents' sociodemographic information, while section B-D elicited information on the study's objectives. The study's in-depth interview was conducted with five (5) staff of Bayelsa State Environmental Sanitation Authority in Yenagoa. Quantitative data collected was analyzed using Chi $(\varkappa 2)$ statistics. The research instruments were evaluated for validity by authorities in Environmental Sociology and their remarks and recommendations on the content and validity of the questionnaire were integrated to enrich the quality of the final questionnaire that was administered. The instruments were double-checked to avoid the presences of conjectures, misrepresentation and misinterpretations. The reliability of the research instrument, which bothered on the consistency of the instrument when administered at different times, was determined during a pre-test.

The basic ethical principles for research involving human subjects as highlighted by Babbie (2013), which includes voluntary participation, no harm to the participants, anonymity, confidentiality, non-deceptiveness, analysis and reporting were strictly adhered to in the study.

\section{STRUCTURAL-FUNCTIONALIST THEORY}

This study was anchored on the structural functionalist theory. It is one of the long-standing theories in sociological studies derived from the classical works of August Comte, Emile Durkheim, and Talcott Parsons. However, Talcott Parsons (1975) expanded the concept. According to the tenets of this theory, there are structures in the society with defined functions and each structure is expected to play its part well to keep the society together. The failure of any 
structure to perform this role is a dysfunction that can affect the entire society. According to the theory, structures or institutions must survive by adapting to changing circumstances by means of interdependence.

Adapted to this study, the theory explains waste management in Amassoma Community as a social phenomenon with a structure in which actors and agencies (being residents and the waste management board) are functional parts with specialized functions working as a whole towards the common goal of delivering effective service (the avoidance of indiscriminate refuse dumping and effective management of waste and ensuring better drains) and carrying out responsibilities in ensuring a clean and safe environment (free from the problem of flooding). Furthermore, it can be deduced that indiscriminate refuse dumping and flooding as a disruption and dysfunction of the environment and the society at large. This disruption on the environment will affect the overall functioning and sustainability of the society.

\section{FINDINGS}

The results presented in this section were the results of the field work of the study carried out in March, 2019. Quantitative data was analysed using the non-parametric method of chi-square ( $x 2)$, while the qualitative data was content analysed.

\section{ANALYSIS AND TESTING OF HYPOTHESES}

The research hypotheses of this research are as follows:

Hypothesis $1: H_{o}$ : There is no relationship between waste disposal habit of the people and flooding in the study area

Hypothesis 2: $H_{o}$ : There is no relationship between poor waste management and flooding in the study area

Hypothesis $3: H_{o}$ : There is no relationship between drains blocked by dumped refuse and flooding in the study area.

The hypotheses are analyzed and interpreted by collating the responses from the questions relevant to testing the hypotheses as seen in Table 1. Chi-square test of significance was used to test the formulated hypotheses at the 5\% level of significance. 
Table 1: Test of hypotheses

\begin{tabular}{|c|c|c|c|c|c|}
\hline Variables & $\begin{array}{l}\text { Strongly } \\
\text { Agree }\end{array}$ & Agree & Disagree & $\begin{array}{l}\text { Strongly } \\
\text { Disagree }\end{array}$ & $\begin{array}{l}\text { Test of } \\
\text { Association }\end{array}$ \\
\hline $\begin{array}{l}\text { The improper dispose of } \\
\text { refuse has affected the } \\
\text { rate of flooding in the } \\
\text { community }\end{array}$ & $\begin{array}{l}198 \\
(52.4 \%)\end{array}$ & $\begin{array}{l}172 \\
(45.5 \%)\end{array}$ & $\begin{array}{l}5 \\
(1.3 \%)\end{array}$ & $\begin{array}{l}3 \\
(0.8 \%)\end{array}$ & $\begin{array}{l}\chi^{2}=350.275 \\
\text { df }=3 \\
\text { Sig. } \\
=<0.001\end{array}$ \\
\hline $\begin{array}{l}\text { Government negligence } \\
\text { about waste control has } \\
\text { affected the rate of } \\
\text { flooding in the } \\
\text { community }\end{array}$ & $\begin{array}{l}265 \\
(70.1 \%)\end{array}$ & $\begin{array}{l}106 \\
(28.0 \%)\end{array}$ & $\begin{array}{l}6 \\
1.6 \%\end{array}$ & $\begin{array}{l}1 \\
(0.3 \%)\end{array}$ & $\begin{array}{l}\chi^{2}=484.413 \\
\mathrm{df}=3 \\
\text { Sig. } \\
=<0.001\end{array}$ \\
\hline $\begin{array}{l}\text { Dumping of refuse in } \\
\text { drainages and rivers } \\
\text { results to flooding in the } \\
\text { community }\end{array}$ & $\begin{array}{l}272 \\
(72.0 \%)\end{array}$ & $\begin{array}{l}97 \\
(25.7 \%)\end{array}$ & $\begin{array}{l}6 \\
(1.6 \%)\end{array}$ & $\begin{array}{l}3 \\
(0.8 \%)\end{array}$ & $\begin{array}{l}\chi^{2}=504.942 \\
\mathrm{df}=3 \\
\text { Sig. } \\
=<0.001\end{array}$ \\
\hline
\end{tabular}

Table 2: Summary of findings of the test of hypotheses

\begin{tabular}{lllll}
\hline & Chi-Square Value & Df & P-Value & Remark \\
\hline Hyp. 1 & 350.275 & 3 & $<0.001$ & Reject Ho \\
Hyp. 2 & 484.413 & 3 & $<0.001$ & Reject Ho \\
Hyp. 3 & 504.942 & 3 & $<0.001$ & Reject Ho \\
\hline
\end{tabular}

\section{DISCUSSION}

In Table 2, hypothesis one tested at 5\% level of significance gave a chi-square value of 350.275 with p-value of $<0.001$. Therefore, there is significant relationship between waste disposal habit and flooding as the p-value of $<0.00$ is less than the level of significance used in the study. Collaborating this finding, were the responses from the interviewees obtained from the study's in-depth interview which noted that:

"People in this community just dump refuse anywhere they choose.

For instance, in front of this street you will see heap of refuse, that's

because people have turned that place into a dumping site. When

everybody is done with their daily work they go and dump there, so

the indiscriminate dumping of refuse is very bad in this community.

(IDI/Woman Leader/Amassoma Community/March $30^{\text {th }}$, 2019). 


\title{
Indiscriminately dumping refuse in drainage can definitely cause flooding because the water won't be able to flow the way it is supposed to and that can increase flooding. " \\ - (IDI/Staff/ Bayelsa State Environmental Sanitation Authority/ March 29th, 2019$)$.
}

Hypothesis two as seen in Table 2 which was tested at 5\% level of significance gave a chi-square value of 484.413 with p-value of $<0.001$. Therefore, there is significant relationship between poor waste management and flooding as the p-value of $<0.001$ is less than the level of significance used in the study. Also, collaborating this finding, were the response from most of the interviewees from the community who noted that the Sanitation Authority were not doing their job of proper waste management.

Finally, hypothesis three tested at $5 \%$ level of significance gave a chi-square value of 504.942 with p-value of $<0.001$. Therefore, there is significant relationship between drains blocked by refuse dump and flooding as the $\mathrm{p}$ value of $<0.001$ is less than the level of significance used in the study. In line with this finding was the response from an interviewee who noted thus:

\footnotetext{
"Indiscriminate refuse dump has blocked all the drainages in this community. When there is flood the water carries the refuse to the shore and when the flood reduces, the waste becomes scattered around the environment because there is no proper waste management."
}

- (IDI/ Chief/Amassoma Community/March 30 ${ }^{\text {th }}, 2019$ )

Confirming this, another said:

\begin{abstract}
“Amassoma doesn't have a well-organized drainage system, what they have is a natural drain system, this is the natural movement of the water bodies. If this natural drain system is kept clean, there would be no flooding but if it's blocked with refuse, it can be very harmful to the environment and cause flooding. Like in year 2012 and last year, how the flooding increased was because the drainage was blocked. Although, for last year flood, it was said to be a result of the increase in the Niger delta basin but what they equally found out was that the flooding would have been lower if the natural drainage was not blocked with refuse."

- (IDI/Head/Bayelsa State Environmental Sanitation Authority/ March 29th, 2019$)$.
\end{abstract}


From the findings above, it can be inferred that indiscriminate refuse dumping causes flooding in Amassoma community. Given that, the study's findings show that there is relationship between the waste disposal habit of the people, poor waste management and drains blocked by dumped refuse and flooding in the study area. The study's finding supports those of Abolade et al. (2013).

\section{RECOMMENDATION}

In light of the study findings, recommendations were made to the study area stakeholders who comprised the residents, waste management board, government and policy makers. Residents should be properly oriented on the need for proper waste disposal as this will ensure their positive attitude towards waste management. The Bayelsa State Environmental Sanitation Authority must ensure concerted efforts in the issue of effective waste management in the community. For the Government and policy makers, beyond the awareness for the need of campaigns on the environmental implication of indiscriminate refuse dumping, there should be laws against such acts enacted and strictly upheld in the community.

\section{CONCLUSION}

The study findings revealed that indiscriminate refuse dumping is a common occurrence and has a significant contributory effect on flooding in Amassoma Community, Bayelsa State. The study pointed out that the poor waste disposal habits of the residents, poor waste management, and drains blocked due to dumped refuse results in flooding in the study area. 


\section{REFERENCES}

Abdullahi, I., Ajibike, M. A., Man-ugwueje, A. P., and Ndububa, O. I. (2014). Environmental impact of indiscriminate waste disposal: A case study of Nigerian Air Force Base Kaduna. International Journal of Engineering and Applied Sciences (IJEAS), 1(1): 25-33. Retrieved on $9^{\text {th }}$ December, 2019 from: https://www.ijeas.org/download_data/view16.pdf

Abolade, O., Muili, A. B. and Ikotun, S. A. (2013). Impact of flood disaster in Agege local government area, Lagos, Nigeria. International Journal of Development and Sustainability. 2(4): 2354-2367. Retrieved on $9^{\text {th }}$ December, 2019 from: https://isdsnet.com/ijds-v2n4-13.pdf

Akindutire, I. O. and Alebiosu, E. O. (2014). Environmental Risk-Factors of Indiscriminate Refuse Disposal in Ekiti State, Nigeria. IOSR Journal of Research \& Method in Education (IOSR-JRME). 4(5): 54-59.

Akinwale, A. A. (2010). Livelihoods and environmental challenges in coastal communities of Nigeria.Journal of Sustainable Development in Africa. 12(8): 79-88. Retrieved on $9^{\text {th }}$ December, 2019 from: https://pdfs.semanticscholar.org/a2e9/1a46d51b9ad4b07bfeafb9360f27613b51c6.pdf

Aliu, A. A. (2017, August 5). Challenges of managing waste disposal in Nigeria. The Guardian. Retrieved on $9^{\text {th }}$ December, 2019 from: https://guardian.ng/saturday-magazine/challenges-of-managing-waste-disposal-in-nigeria/

Aziale, L. K., and. Asafo-Adjei. E (2013). Logistic challenges in urban waste management in Ghana: A case of Tema metropolitan assembly. European Journal of Business and Management. 5(32): 116-128.

Babbie, E. R. (2013). The practice of social research, (13th ed., International Edition, pp. 32-42). Belmont, California: Wadsworth Publishing Company.

Cochran, W. G. (1939). The use of the analysis of variance in enumeration by sampling. Journal of the American Statistical Association, 34: 207, 492-510. doi: 10.1080/01621459.1939.10503549

Ezechi, E. H., Nwabuko, C. G., Enyinnaya, O. C., and Babington, C. (2017). Municipal solid waste management in Aba, Nigeria: Challenge and prospects. Environment Research, 22:231-236.

Ifeoluwa, O. B. (2019). Harmful effects and management of indiscriminate solid waste disposal on human and its environment in Nigeria. Global Journal of Research and Review, 6(1): 20-49.doi: 10.21767/2393-8854.100043

Karanja, T. B. (2015). Challenges of environmental waste management on social economic development of Nigeria, International Journal of Innovations in Medical Science, 3(1): 14-24.

Krejcie, R. V. and Morgan, D. W. (1970). Determining sample size for research activities. Educational and Psychological Measurement, 30:607-610. Retrieved on $9^{\text {th }}$ December, 2019 from: https://home.kku.ac.th/sompong/guest_speaker/KrejcieandMorgan_article.pdf

National Bureau of Statistics, (2017) Social Statistics in Nigeria: NBS Report. Retrieved on $9^{\text {th }}$ December, 2019 from: http://www.citypopulation.de/php/nigeria-admin.php?adm1id=NGA006

Ogweleke, O. (2009). Municipal solid waste management in Port Harcourt, Nigeria: Obstacles and prospects. Management of Environmental quality, 15(4): 38-39. 
Olayiwola, H. A., AbuduLawal, L. andAdewuyi, G. K. (2017). Effects of indiscriminate solid waste disposal and environmental issues in Ibadan South West Local Government, Oyo State, Nigeria. Journal of Natural Sciences Research, 7(10): 87-97.

Omolawal, S. A. and Shittu, O. (2016) Challenges of solid waste management and environmental sanitation in Ibadan North Local Government, Oyo State, Nigeria. African Journal of Social Science, 19(1): 129-142. Retrieved on $9^{\text {th }}$ December, 2019 from: https://www.ajol.info/index.php/ajpssi/article/view/136912

Onifade, O. A. and Nwabotu (2014) Implications and causes of illegal refuse dumps in Ilorin South Local Government Area, Kwara State. Arabian Journal of Business andManagement Review, 4(2): 148-155. Retrieved on $9^{\text {th }}$ December, 2019 from: https://www.arabianjbmr.com/pdfs/OM_VOL_4_(2)/13.pdf

Taiwo, P. A. and Ajayi, J. O. (2013). Environmental pollution in urban market: The case of Bodija market, Ibadan, Nigeria, The International Institute for Science, Technology and Education (IISTE),3(13): 53-67. Retrieved on $9^{\text {th }}$ December, 2019 from: https://www.iiste.org/Journals/index.php/DCS/article/view/9412/9634

Talcott, P. (1975). The present status of structural-functional theory in sociology, social systems and the evolution of action theory. New York, NY: The Free Press. 